\title{
KINGA ROZWADOWSKA
}

iD https://orcid.org/0000-0002-6279-0082

Uniwersytet Jagielloński

kinga.rozwadowska@uj.edu.pl

\section{KRYTYKA PRZEKŁADU W CYBERPRZESTRZENI - NOWE SZANSE I WYZWANIA (NA PRZYKŁADZIE TŁUMACZEŃ MISTRZA I MAŁGORZATY MICHAIŁA BUŁHAKOWA)}

\section{Abstract \\ Translation Criticism in Cyberspace - New Opportunities and Challenges (on Polish Translations of Mikhail Bulgakov's The Master and Margarita)}

The ongoing digitization of the literary heritage together with the growing competition between publishing houses have led to a situation where translation series of works considered as canonical changed their form of extending from diachronic, linear development in time to synchronic "explosion" of parallel texts, which task is to win readers-consumers with advantages of novelty, distinctness, "inventiveness." Such translations gain a new function - they become a marketing tool for publishing houses. In my opinion the newest retranslations of Mikhail Bulgakov's The Master and Margarita is one of the most interesting examples of the process described above. In recent years, new Polish versions of this novel have been published at a dizzying pace (five new translations between 2015 and 2018) and in overwhelming welth (five editions were published in four different translations in 2018 alone). The new translations of Bulgakov's novel evoke a lively response from the audience. All sorts of analysis, comparisons and opinions have been published not only in scientific journals, but also in daily newspapers, internet forums and in comments in online bookstores. In the Internet, professional translation criticism coexists with private opinions of Internet users (often based on non-literary factors) and with marketing content, advertisements, and blurbs deliberately formed as reviews. In this paper I would like to discuss new roles of professional translation criticism in circumstances described above, analyse its presence in the Internet and try 
to define its new objects. On the one hand, its voice should be loud and clear enough to be heard in the virtual chaos of texts, on the other hand - persuasive and lucid enough to help readers to become aware of decisions they make by choosing a particular translation and perceive the literary value of texts hidden behind attractive covers of new editions.

Keywords: translation criticism, The Master and Margarita, retranslations, online journals

Słowa kluczowe: krytyka przekładu, Mistrz i Małgorzata, serie przekładowe, czasopisma online

„Nie polecam. Tłumaczenie okrojone o 200 stron. Chcę zwrócić tę pozycję" - to jeden z komentarzy przywołanych przez Joannę Barańską w artykule opublikowanym na portalu Onet.pl. 21 sierpnia 2020 roku. Tekst poświęcony jest kontrowersjom, jakie wśród klientów sieci Empik wzbudziło wznowienie najstarszego, mocno okrojonego przekładu Braci Karamazow Dostojewskiego autorstwa Barbary Beaupré. Celowo piszę tu o klientach, nie o czytelnikach, gdyż przytoczone w powyższym tekście komentarze stanowią interesującą mieszaninę uwag wartościujących tekst z ocenami jakości książki jako produktu. Czy krytyka przekładu rzeczywiście przybrała nową formę i przeniosła się do internetu w postaci ocen oraz komentarzy wystawianych przez konsumentów w księgarniach internetowych, takich jak Empik czy Amazon?

Poszukując odpowiedzi na to pytanie, należy mieć przede wszystkim na uwadze fakt, że pod pojęciem krytyki przekładu kryje się pewne spektrum praktyk translatologicznych: w artykule Edwarda Balcerzana pt. Tajemnica istnienia (sporadycznego) krytyki przekładu nacisk położony jest na ,aktywność aksjologiczną", która stanowi nie tyle cechę szczególną krytyki przekładu, ile zjawisko charakterystyczne dla szeroko pojętego przekładoznawstwa: „Translatologia [...] nie przestaje być dziedziną wartościującą, oceniającą, doradczą" (Balcerzan 2011: 174). Z kolei Ewa Kraskowska podkreśla aspekty badawcze krytyki przekładu: teoretyczny, analityczny i interpretacyjny (Kraskowska 2018: 54). Obydwoje zgadzają się natomiast co do nadrzędnego celu krytyki przekładu, rozumianego jako ,uwrażliwianie na paradoksalny fenomen translacji” (Kraskowska 2018: 54) czy też, jak to ujmuje Balcerzan: „Podstawowym dążeniem krytyki translatorskiej pozostaje więc - tak czy inaczej - ostrzeżenie lekturowe: znak inności, który ma przeciwdziałać naiwnemu zaufaniu wobec decyzji tłumacza" (Balcerzan 
2011: 181). W niniejszym artykule zamierzam rozpatrywać powyższe aspekty krytyki przekładu przejawiające się w rozmaitych formach wypowiedzi obecnych w internecie: od artykułów naukowych po materiały marketingowe. Na wybranych przykładach postaram się pokazać, jak rozproszenie krytyki przekładu w cyberprzestrzeni może stać się siłą tej dziedziny i realizować powyżej sformułowany cel.

Mary Wardle, autorka artykułu Eeny, Meeny, Miny, Moe: The Reception of Retranslations and How Readers Choose, dostrzega i opisuje przemianę formy recenzowania przekładów z profesjonalnego (publikowanego głównie w druku) do powszechnego (funkcjonującego online) (Wardle 2019: 227). Postępująca cyfryzacja dziedzictwa literackiego sprawiła nie tylko, że teoretycznie każdy użytkownik może się wypowiedzieć w sieci na temat każdego tekstu, ale przede wszystkim - i to mocno podkreśla Wardle - zmieniła obieg serii przekładowych z diachronicznego na synchroniczny. Dzięki księgarniom internetowym czytelnicy coraz częściej mają dostęp do tak dużego wyboru tłumaczeń, jak nigdy wcześniej. Stają zatem przed wyborem, którego w poprzednim stuleciu nie mieli lub mieli w bardzo ograniczonym zakresie. Poniżej przedstawię współczesny obieg polskich tłumaczeń powieści Macmep u Mapzapuma Michaiła Bułhakowa w internecie, spróbuję wskazać, jakie problemy i wyzwania stawia on krytyce przekładu oraz przyjrzę się tekstom poświęconym wybranym przekładom, które mierzą się z nimi na różne sposoby.

Nowe thumaczenia Mistrza i Małgorzaty ukazują się w ostatnich latach w tak zawrotnym tempie i w takiej obfitości, że chyba można już mówić o „klęsce urodzaju”. W 2015 roku tłumaczenie Julii Celer publikuje wydawnictwo Greg, specjalizujące się w publikacji lektur szkolnych z opracowaniem. W 2016 roku pojawiają się kolejne dwa przekłady: Leokadii, Igora i Grzegorza Przebindów w prestiżowej serii wydawnictwa Znak: ,50 na 50”, ale również w edycji poza tą serią, oraz Krzysztofa Tura (Fundacja Sąsiedzi). W roku 2017 ukazuje się przekład Jana Cichockiego, a w 2018 roku - Barbary Dohnalik. Wszystkie te thumaczenia są prawie co roku wznawiane, a do tego zbioru dochodzą jeszcze wznowienia starszych tłumaczeń (pierwszego, autorstwa Ireny Lewandowskiej i Witolda Dąbrowskiego z 1969 roku, oraz Andrzeja Drawicza z 1995 roku). W samym 2018 roku opublikowano pięć wydań powieści Bułhakowa w czterech różnych tłumaczeniach, a ogółem w latach 2015-2020 ukazało się czternaście różnych wydań tego dzieła ${ }^{1}$.

${ }^{1}$ Dane według katalogu Biblioteki Narodowej na dzień 4 lutego 2021 roku. 
Co wywołało tę lawinę tekstów pod wspólnym tytułem: Mistrz i Małgorzata? Powieść od lat cieszy się w Polsce niesłabnącą popularnością, ale jeszcze do niedawna popularność tę zawdzięczała wyłącznie przekładowi Lewandowskiej i Dąbrowskiego. Dlaczego więc w ostatnich latach nowe tłumaczenia ukazują się w tak przytłaczającej obfitości i rozmaitości? Teorii na temat przyczyn rozwoju serii przekładowych jest wiele, ja w niniejszym artykule skupię się na perspektywie socjologicznej i ekonomicznej. Badacze analizujący przekłady pod tym kątem dostrzegają niebagatelny wpływ publikowania książek z tzw. kanonu na wyniki finansowe danego wydawnictwa (klasyka, a zwłaszcza lektury szkolne, to dla wydawców po prostu bezpieczna i pewna inwestycja), a także na aspekty niewymierne finansowo, ale również istotne dla funkcjonowania na rynku wydawniczym, takie jak prestiż (Wardle 2019: 218). Jak stwierdzili Johan Heilbron i Gisèle Sapiro, wydawanie przekładów dzieł kanonicznych „to sposób zdobywania symbolicznej władzy przez wydawcę, któremu brak kapitału ekonomicznego lub kulturalnego" (Heilbron, Sapiro 2007: 103 - przekład KR). Nie powinno nas zatem dziwić, że wobec rosnącej konkurencji na rynku wydawniczym wzrasta też liczba publikacji dzieł już znanych, cenionych i często od dawna obecnych w obiegu czytelniczym w starszych przekładach. W rezultacie w dniu, w którym piszę te słowa (3 lutego 2021) duże księgarnie internetowe posiadają $\mathrm{w}$ swojej ofercie jednocześnie od kilku do kilkunastu różnych wydań różnych przekładów (brałam pod uwagę wspomniany już Empik, Bonito i Świat Książki). Czytelnicy mają więc w czym wybierać ale jak podejmują decyzję? Jakimi kryteriami się kierują? Mary Wardle na przykładzie analizy obiegu włoskich tłumaczeń Wielkiego Gatsby'ego Fitzgeralda i angielskich tłumaczeń Księcia Machiavellego stwierdza, że większość czytelników dokonuje wyboru głównie pod wpływem splotu różnych czynników „«zewnętrznych», (tj. pozaliterackich - KR), takich jak dostępność, strategie marketingowe, cena, widoczność, sieć dystrybucji wydawnictw, rankingi na podstawie przyznanych gwiazdek czy opinie innych konsumentów" (Wardle 2019: 235).

Jeżeli wymienione powyżej czynniki determinują wybory czytelników, to dzieje się tak dlatego, że sam tekst tłumaczenia jest dla nich ,przezroczysty", jest wiernym odbiciem oryginału - albo powinien nim być. Gdy dzieje się inaczej, rozczarowany klient domaga się zwrotu poniesionych kosztów. Tutaj właśnie otwiera się pole do aktywnej działalności krytyków przekładu, którzy pokazywaliby, że to, co różni książki podpowiadane nam przez wyszukiwarkę po wpisaniu tytułu, to nie tylko okładka i cena. W niniejszym 
artykule stawiam sobie za cel przeanalizowanie obecności krytyki przekładu w wirtualnej przestrzeni oraz tego, jakie przybiera ona formy $i$ jak zmienia się jej język pod wpływem wymienionych powyżej przemian obiegu tłumaczeń, a także przemian samego rynku wydawniczego.

Najpierw wróćmy do opisanego na samym początku ,skandalu przekładowego", którego źródłem jest niekompletność tekstu tłumaczenia Braci Karamazow. W przypadku jednego z najnowszych tłumaczeń powieści Bułhakowa również mamy do czynienia ze skandalem, ale tym razem wiąże się on nie ze skrótami, lecz z nadmiarem.

Autorką tego przekładu jest Barbara Dohnalik, a jej - łagodnie mówiąc - kontrowersyjne strategie przekładowe zdemaskował Aleksander Wawrzyńczak w artykule pt. Buthakow zmanipulowany czyli o ,fachowym $i$ wybitnym” przekładzie „,Mistrza i Małgorzaty”. Tytułowy cudzysłów, w który zostały ujęte epitety określające tłumaczenie, nie pozostawiałyby wątpliwości co do tego, że jego ocena nie będzie pochlebna, jednak sam autor problematyzuje formę swojej wypowiedzi jako krytyki przekładu: „Nie zamierzam przeprowadzać szczegółowej jego analizy, gdyż ze względu na niską wartość na nią nie zasługuje” (Wawrzyńczak 2019: 112). Analiza filologiczna jest podstawą czy też punktem wyjścia dla krytyki przekładu (Kraskowska 2018: 59), zatem z przymrużeniem oka można by wytknąć Wawrzyńczakowi, że w dalszej części tekstu nie wywiązuje się z powyższej deklaracji, kiedy stwierdza, że tłumaczenie jest filologicznie w miarę poprawne, ale to za mało, by nazwać je dobrym przekładem. Na dowód podaje szereg stylistycznych niezręczności, które w zestawieniu z oryginałem dowodzą, zdaniem autora, że priorytetem tłumaczki było dosłowne przełożenie znaczeń, kosztem melodyki i stylu tłumaczenia (Wawrzyńczak 2019: 112-113).

Drugim wartym odnotowania szczegółem jest zasygnalizowana w samym już tytule polemika krytyka z wydawcą. Epitety „fachowy” i ,wybitny” pochodzą z blurbu, czyli tekstu stricte marketingowego. Pojawia się on nie tylko na tylnej okładce i na stronie wydawnictwa, ale jest też kopiowany przez księgarnie prowadzące sprzedaż internetową. W rezultacie funkcjonuje on w sieci na podobnych prawach jak teksty krytyczne, a z pewnością jest bardziej widoczny, przez co niewprawnemu czytelnikowi łatwo będzie pomylić go z recenzją. Do strategii marketingowych stosowanych przez wydawnictwa w odniesieniu do tłumaczeń powrócę jeszcze w dalszej części tekstu.

Aleksander Wawrzyńczak w swoim artykule przeciw przekładowi Dohnalik i przeciw samej tłumaczce wytacza cały szereg poważnych zarzutów. 
Zwraca między innymi uwagę na to, że w posłowiu Dohnalik powołuje się na niesprawdzone hipotezy, plotki i insynuacje dotyczące autora Mistrza i Małgorzaty oraz samego dzieła, i przedstawia je jako fakty, nie podając ani źródeł, ani dowodów; że proponuje nieuzasadnione tropy interpretacyjne - na przykład rzekome polonica w powieści (Wawrzyńczak 2019: 110-112), ale przede wszystkim - i to już jest zarzut dotyczący samego tekstu tłumaczenia - że dopisuje do powieści fragmenty, których nie ma $\mathrm{w}$ oryginale, a które $\mathrm{w}$ zamierzeniu mają zapewne potwierdzać interpretację thumaczki zaprezentowaną w posłowiu ${ }^{2}$. Warto jednak podkreślić, że w konkluzji wieńczącej artykuł Wawrzyńczak wskazuje innych agentów, którzy przyczynili się do wydania przekładu:

Zasadne jest pytanie o moralną odpowiedzialność tych, którzy za tym wydaniem stoją, przy czym nie chodzi tu bynajmniej o thumaczkę, której obce są odpowiedzialność, rzetelność i przyzwoitość. To pytanie do wydawcy, działającego na rynku już kilkanaście lat (od 2002 roku) i mogącego pochwalić się różnorodną, atrakcyjną ofertą, w tym wydaniami znanych i cenionych pisarzy i filozofów [...]. Profesjonalnego podejścia i edytorskiej rzetelności w tym konkretnym przypadku - wydania Mistrza i Małgorzaty w przekładzie i z komentarzami Barbary Dohnalik - po prostu zabrakło (Wawrzyńczak 2019: 119-120).

To w moim przekonaniu bardzo ważne, że krytyk poruszył kwestie etyczne, równocześnie poniekąd odciążając niekompetentną tłumaczkę i rozkładając ciężar odpowiedzialności na wydawców oraz edytorów. W badaniach nad przekładami, mówiąc coraz częściej i coraz donioślej o emancypacji tłumaczy, o ich wychodzeniu z cienia i ujawnianiu się jako twórców, nie należy zapominać o tych, którzy wciąż są tak niewidzialni, jak do niedawna niewidzialni byli tłumacze - o tych, którzy odpowiedzialni są za nieartystyczną, co nie znaczy, że nieistotną stronę publikacji danego przekładu (Buzelin 2007). Jeżeli użytkownicy internetu - czytelnicy - konsumenci postrzegają przekład jako produkt, to w mojej opinii należy pokazywać im proces powstawania tego produktu i wskazywać wszystkich agentów w ten proces zaangażowanych. Wierzę, że jeśli dowiedzą się, od jak wielu ludzi

${ }^{2}$ W skrupulatnie wyliczonych przez Wawrzyńczaka fragmentach dopisanych przez Dohnalik najbardziej interesujące wydaje mi się to, że treść niektórych sprawdziłaby się w formie przypisów od tłumaczki (zob. objaśnienie słowa „turnikiet” - Wawrzyńczak 2019: 113-114), jednak woli ona uprawomocnić je autorytetem autora oryginału, zamieszczając w tekście głównym. Co więcej, przypisami opatruje fragmenty dopisane przez siebie (zob. Wawrzyńczak 2019: 115). 
i jak wielu zmiennych czynników zależy efekt w postaci tłumaczenia, które zamierzają kupić, dostrzegą też, że sam proces nie był ani odtwórczy, ani mechaniczny, lecz kreatywny. Może dzięki temu będzie też mniej gniewnych żądań zwrotu pieniędzy za wybrakowane tłumaczenie...

Co ważne, Wawrzyńczak zaznacza, że działalność Barbary Dohnalik jako popularyzatorki Bułhakowa (szkodliwa, w ocenie autora artykułu) jest znana naukowcom co najmniej od 1989 roku, kiedy to opublikowała zbiór opowiadań Bułhakowa w swoim tłumaczeniu pt. Pan Pitsudski i inne opowiadania. Problem w tym, że „sześciu spośród dziewięciu zamieszczonych tam tekstów autor Mistrza i Matgorzaty nigdy nie napisał!" (Wawrzyńczak 2019: 107). Publikacja wywołała skandal wśród znawców, którzy szybko zdemaskowali mistyfikację Dohnalik. Wawrzyńczak zwraca jednak uwagę na to, że „krytyczne opinie zamieszczane w niskonakładowych naukowych czasopismach nie mogły zyskać szerszego rozgłosu, toteż literackie harce pani Dohnalik pozostały dla wielu tajemnicą” (Wawrzyńczak 2019: 108). Warto zatrzymać się przy tych słowach, by spojrzeć na nie w kontekście przytoczonych przeze mnie wcześniej spostrzeżeń Mary Wardle dotyczących wyjścia praktyk recenzowania poza krąg profesjonalistów i upowszechnienia ich przez zwykłych czytelników w internecie. Przeciwstawienie profesjonalnego, czyli drukowanego powszechnemu, czyli internetowemu wydaje się zbyt dużym uproszczeniem. Sam artykuł Wardle dostępny jest w całości online, podobnie jak tekst Wawrzyńczaka, opublikowany w „Przeglądzie Rusycystycznym”, który ukazuje się zarówno w wersji papierowej, jak i online. Jest to oczywiście czasopismo naukowe, specjalistyczne, jednak po wpisaniu do wyszukiwarki słów "mistrz i małgorzata dohnalik" recenzja Wawrzyńczaka jest pierwszym podpowiadanym wynikiem (stan na 5 lutego 2021 roku), zatem czytelnik zainteresowany tym konkretnym thumaczeniem nie będzie miał problemu ze zdobyciem informacji na jego temat. O wynikach wyszukiwania pozostałych tłumaczeń wspomnę jeszcze w dalszej części artykułu.

Wysokie pozycjonowanie w wyszukiwarce to jednak niejedyny czynnik, który ułatwia rozpowszechnianie wiedzy na temat tłumaczeń wśród czytelników nieprofesjonalnych. Tekst Wawrzyńczaka przyciąga uwagę również brawurowym stylem, niepozbawionym radykalnych ocen wyrażonych w emocjonalny sposób, często potocznym językiem, na przykład: „insynuacjami sypie ona jak z rękawa” (Wawrzyńczak 2019: 111); „To dopiero początek radosnej twórczości tłumaczki, która w kolejnych rozdziałach wyraźnie się rozkręca” (Wawrzyńczak 2019: 114); „Zaczniemy od 
«perełki» zaserwowanej czytelnikowi na stronie 166" (Wawrzyńczak 2019: 117). Recenzja Wawrzyńczaka ma niewątpliwie charakter interwencyjny, to głos jednocześnie znawcy i oburzonego czytelnika. Jego cel w szerszej perspektywie pozostaje zbieżny z celem Joanny Barańskiej, która na portalu Onet.pl pisała o wznowieniu najstarszego przekładu Braci Karamazow: jest to nagłośnienie nagannych praktyk translatorskich i wydawniczych. Na tych dwóch przykładach widać wyraźnie, że nie można pisać o jednych, przemilczając drugie, że warto je rozpatrywać również jako całość, czyli „,produkt” oferowany czytelnikowi. W mojej opinii dzięki przystępnemu, niepozbawionemu ironii i humoru stylowi artykuł Aleksandra Wawrzyńczaka mógłby z powodzeniem zostać również opublikowany na jednym z portali o zasięgu ogólnokrajowym, i tym samym dotrzeć do większego kręgu odbiorców.

Drugim przykładem tekstu zawierającego elementy krytyki przekładu i mogącego potencjalnie dotrzeć do względnie szerokiego kręgu czytelników nieprofesjonalnych jest artykuł Narzan, zubrik i pepegi autorstwa Bożeny Witowicz, opublikowany drugi raz pod tytułem Co wyczytali thumacze wnajnowszych przekładach „Mistrza i Matgorzaty” na stronie Stowarzyszenia Tłumaczy Literatury. Pierwotnie tekst zamieszczony został w tygodniku „Przegląd” z 2 stycznia 2018 roku, zarówno w wersji papierowej, jak i online. Pod względem stylu i obranych celów artykuł ten umiejscowiłabym na przeciwległym biegunie w stosunku do tekstu Wawrzyńczaka. Nie bez znaczenia pozostaje oczywiście moment opublikowania recenzji Witowicz: pojawia się ona po wydaniu pierwszych trzech XXI-wiecznych przekładów, a jeszcze przed ukazaniem się kontrowersyjnego tekstu Barbary Dohnalik. Autorka z uznaniem pisze o Janie Cichockim, Grzegorzu Przebindzie i Krzysztofie Turze jako o tłumaczach-ekspertach, bułhakoznawcach.

O ile autora omówionej wcześniej recenzji można by nazwać krytykiem-demaskatorem, o tyle Witowicz jawi się jako krytyk-popularyzator, ponieważ realizuje wspomniany przeze mnie wcześniej cel krytyki przekładu rozumiany jako „uwrażliwianie na paradoksalny fenomen translacji” (Kraskowska 2018: 54). Tekst napisany jest bardzo przystępnym językiem i bez wątpienia skierowany do czytelnika nieprofesjonalnego. Autorka zwraca uwagę na przykład na nieprzezroczystość przekładu: „Rzadko jednak czytelnicy zdają sobie sprawę, że jedną z tajemnic sukcesu takich książek stanowi przekład. [...] Tymczasem przekład ma niebagatelny wpływ na odbiór: zły może zgubić dzieło wybitne, świetny - przeciętną książkę wynieść na szczyt”. Podkreśla, że tłumaczenie to pewna interpretacja oryginału i tym samym nigdy nie jest ostateczne: „Podobnie jak każda lektura przekład jest 
najpierw i przede wszystkim interpretacją. Każdy czytelnik inaczej rozumie tekst, a im bardziej jest on złożony, tym więcej może mieć odczytań"; objaśnia, że tłumaczenie jest procesem twórczym: „Tłumacz tworzy dla czytelnika tekst na nowo, twórczo rozwija sensy, język i rytm dzieła, przy jednoczesnej trosce o zachowanie bliskości z oryginałem, w tym językiem autora" (Witowicz 2018). Witowicz, zestawiając fragmenty starszych thumaczeń (Lewandowskiej i Dąbrowskiego oraz Drawicza) z trzema powstałymi w XXI wieku, pokazuje czytelnikowi wybory, przed jakimi stanęli thumacze, i strategie, jakie przyjęli. Na licznych przykładach objaśnia między innymi pojęcia egzotyzacji i udomowienia.

Co ważne, Bożena Witowicz zwraca uwagę na nieoczywistość, niestabilność oryginału. Mistrz i Małgorzata jest wszak dziełem tworzonym oraz korygowanym przez Bułhakowa przez lata, i ostatecznie nieukończonym. Warto na chwilę zatrzymać się przy tej kwestii, ponieważ ta niedefinitywność oryginału stała się w jakiś sposób elementem strategii marketingowych różnych wydawnictw. Na przykład wydawnictwo Greg ogłosiło: „Powieść w całkowicie nowym, pełnym tłumaczeniu, zgodnym z oryginałem i pozbawionym cięć dokonanych na nim przez rosyjską cenzurę!”. Autor tego cytatu sprytnie połączył atut nowości z iluzją pełnej ekwiwalencji i nutką sensacji, ukrytą w sugestii, że oto czytelnik otrzymuje coś, co wcześniej było zakazane (tymczasem, jak wiadomo, fragmenty usunięte przez cenzurę przywrócono w pierwszym polskim tłumaczeniu Mistrza i Małgorzaty autorstwa Lewandowskiej i Dąbrowskiego już w 1980 roku). Swoją drogą interesujące jest to, jak różnie wydawcy prezentują czytelnikom pojęcie „kompletności” powieści w zależności od reklamowanego tłumaczenia. W przywołanym powyżej cytacie chodzi o przywrócenie treści usuniętych przez cenzurę z przyczyn politycznych, ale już w tekście reklamującym tłumaczenie Krzysztofa Tura pojawia się inne rozumienie oryginału jako całości:

Tłumacz Krzysztof Tur uzupełnił swój przekład fragmentami wczesnych wersji powieści: przypominają one pierwotny zamysł autorski, jeszcze nieskrępowany cenzurą $\mathrm{i}$,zawierają wartości, które wyparowały $\mathrm{z}$ wersji ostatecznej”. Nikt z jego poprzedników o takie zestawienie się nie pokusił, jest to więc w jego książce niewątpliwa nowość (Wołodźko-Butkiewicz 2016)³.

${ }^{3}$ W przypadku tego cytatu warto też zwrócić uwagę na fakt, że pochodzi on z recenzji Alicji Wołodźko-Butkiewicz zamieszczonej na okładce wydania. Fragment ten jest kopiowany przez księgarnie internetowe na przemian z drugą znajdującą się na okładce recenzją, 
Z kolei w przypadku publikacji przekładu Jana Cichockiego podstawą jest ostatnia - szósta wersja powieści.

Skomplikowany proces powstawania powieści Bułhakowa i jej zawiłe losy po śmierci autora otwierają rozmaite możliwości definiowania oryginału, zarówno przez samych tłumaczy, jak i przez tych, którzy tłumaczenia reklamują. W interesie wydawców jest „ustabilizowanie” czy też „ujednoznacznienie” oryginału po to, by uprawomocnić nim wydany przez siebie przekład. Dlatego w mojej opinii jednym z zadań krytyki przekładu powinno być zwracanie uwagi czytelników również na źródło przekładu, które dla wielu może wydawać się „dane raz na zawsze” i niepodlegające zmianom, na skutek czego wydawcy mogą z powodzeniem stosować wobec nich strategię marketingową ,jedynej słusznej wersji”. Witowicz w swoim tekście realizuje ten postulat: przedstawia w skrócie zawiłą historię oryginału i uświadamia odbiorcom, że jego otwarta forma jest jedną z przyczyn rozbieżności między tłumaczeniami.

W toku pracy powstały wersje do tego stopnia rozbieżne, że obecnie badacze wyróżniają ich sześć. W zależności od tego, którą wersję thumacz wybrał jako podstawę thumaczenia - a panuje tu pełna dowolność - tak różne mogą być przekłady.

Polskie bazują na czterech spośród sześciu wersji oryginału (Witowicz 2018).

Powyższa uwaga wydaje mi się cenna tym bardziej, że choć na temat powstawania i przemian Mistrza i Małgorzaty za życia Bułhakowa oraz po jego śmierci napisano wiele, są to teksty na ogół trudniej dostępne dla czytelników nieprofesjonalnych ${ }^{4}$.

Z kolei wspomniany wcześniej walor nowości to oczywiście dobrze znana krytykom przekładu strategia polegająca na kreowaniu złudzenia, że skoro pojawiło się nowe tłumaczenie, to z poprzednim(i) musiało być coś nie tak (Wardle 2019: 233). Wydawnictwa posługujące się przekładami jako narzędziami marketingowymi odmieniają słowo „nowość” przez wszystkie

autorstwa Waldemara Smaszcza. Oba teksty są często rozpowszechniane w internecie w tym również na stronie „Fundacji Sąsiedzi” - jako opis wydawcy.

${ }^{4}$ Najważniejsze ustalenia i tezy rosyjskich badaczek (m.in. Lidii Janowskiej, Anny Saakianc, Jeleny Kołyszewej) dotyczące podstawy tekstowej powieści nie zostały przetłumaczone na język polski. Zebrał oraz podsumował je w swoim artykule Grzegorz Przebinda, kreśląc pasjonującą historię badań tekstologicznych nad rękopisami Mistrza i Małgorzaty (Przebinda 2019). 
przypadki, na przykład: „To nowe, znakomite tłumaczenie tej niezwykłej powieści” (Fundacja Sąsiedzi); „Najsłynniejsza powieść Michaiła Bułgakowa, w Polsce pisanego z niewiadomych powodów zawsze Bułhakow, w nowym rewelacyjnym przekładzie Barbary Dohnalik” (Vis-a-vis Etiuda); „Oferują nowy klucz do odczytania tej wielkiej księgi, przybliżając ją współczesnemu czytelnikowi” (Znak). Walor nowości ma zarówno pozyskać kolejnych czytelników, jak i skusić miłośników Mistrza i Małgorzaty, którzy będą chcieli zapoznać się z inną wersją ukochanej powieści. Skoro, jak zauważył Edward Balcerzan, nawet krytycy przekładów są niekiedy skłonni ulec ,złudzeniu, iż ten przekłada najlepiej, kto przekłada ostatni” (Balcerzan 2011: 183), to co dopiero mówić o zwykłym czytelniku, zagubionym w gąszczu reklam nierzadko udających recenzje tłumaczeń!

Wracając do artykułu Bożeny Witowicz, zauważmy przede wszystkim, że powstrzymuje się ona od oceny wyborów tłumaczy, a jeśli to robi, to tylko w formie subtelnej sugestii i w odniesieniu do pojedynczych zagadnień, nie zaś do całości tekstu. Oto przykład:

Obuwie z płótna na gumowej podeszwie, które w powieści nosił Iwan Bezdomny, oddane zostało przez Cichockiego jako czarne pepegi, co pochodzi od skrótu PPG - Polski Przemysł Gumowy. Teraz rzadko już się słyszy to słowo i zazwyczaj wybierane są - co też uczynili pozostali tłumacze - czarne tenisówki. Pepegi zdają się tutaj o tyle mniej adekwatne, że akcja powieści rozgrywa się w latach 30. w Moskwie, co nie wiąże się ani z Polską, ani z jej przemysłem. $Z$ drugiej strony pepegi istniały u nas już w okresie międzywojennym, można zatem przyjąć, że tłumacz zastosował pojęcie odpowiednie do realiów oryginału (Witowicz 2018).

Witowicz nie wypełnia zatem do końca tej powinności krytyki przekładu, którą Balcerzan nazywa „aktywnością aksjologiczną” (Balcerzan 2011: 174), ponieważ za główny cel stawia sobie popularyzację wiedzy o rozmaitych wariantach powieści Bułhakowa i o przyczynach różnorodności przekładów oraz zachęcenie czytelników do zapoznania się ze wszystkimi tłumaczeniami i docenienia wysiłku, jakiego dokonali ich autorzy, by wzbogacić rodzimą literaturę o nowe wersje znakomitej rosyjskiej powieści: „I czytając pięć tłumaczeń, mamy szansę nie tylko podziwiać wysiłek (ba! kunszt) translatorski kilku osób, zastanowić się, jakich wyborów sami dokonalibyśmy na ich miejscu, ale i przeżyć wielką duchową przygodę" (Witowicz 2018). Stąd w jej tekście znajdziemy więcej pytań i przypuszczeń niż odpowiedzi i rozstrzygnięć. Jeśli można mówić o interwencyjnym charakterze tego artykułu, 
to tylko w znaczeniu uwrażliwienia czytelnika na wybór, którego dokonuje, kupując konkretny przekład, nie zaś - jak w przypadku Wawrzyńczaka demaskowania błędów, a nawet mistyfikacji dokonywanych przez tłumacza.

Skoro wspominałam wcześniej o pozycjonowaniu artykułu Wawrzyńcza$\mathrm{ka}-\mathrm{a}$ jest to moim zdaniem istotny symptom obecności krytyki przekładu w sieci - warto dodać, że dzięki ponownemu opublikowaniu artykułu Witowicz na stronie Stowarzyszenia Tłumaczy Literatury pojawia się on jako pierwsza podpowiedź przy wyszukiwaniu informacji na temat tłumaczeń Mistrza i Małgorzaty w ogóle (po wpisaniu frazy: „mistrz i małgorzata tłumaczenia") lub konkretnie tłumaczenia Jana Cichockiego (stan na 16 lutego 2021 roku). Istnieje więc niemałe prawdopodobieństwo, że czytelnik nieprofesjonalny po zapoznaniu się z tekstem Witowicz dokona świadomego wyboru i być może również w przyszłości będzie zwracał uwagę na to, jakie przekłady interesującej go/ją książki są dostępne w sprzedaży.

Jeśli natomiast czytelnik-internauta zainteresowany jest przekładem Mistrza i Matgorzaty autorstwa Julii Celer, bez trudu odnajdzie w sieci artykuł Moniki Sadowskiej pt. Elementy trzeciej kultury w przekładach polskich wersji „Mistrza i Małgorzaty” Michaiła Buthakowa, opublikowany w czasopiśmie naukowym „Acta Polono-Ruthenica”, wydawanym zarówno w wersji papierowej, jak i elektronicznej. Trudniej będzie natomiast przyswoić zawarte w nim informacje oraz tezy: artykuł ma charakter ściśle naukowy i skupia się na bardzo wąskim aspekcie porównania najnowszych przekładów - nazwach własnych i formach specyficznych dla biblijnych wątków powieści. Bez wątpienia jest on skierowany do wąskiego kręgu odbiorców-profesjonalistów. Dla niewprawnych czytelników interesujące mogą być jednak zestawienia tych nazw w tabelach, które w klarowny sposób obrazują różnice pomiędzy udomowieniem i egzotyzacją, oraz zamieszczone na początku i w zakończeniu artykułu cenne uwagi odnoszące się do projektowanych odbiorców przekładu. Sadowska wykazuje bowiem w swoim artykule, że strategie przekładowe są od nich w dużym stopniu zależne:

autorka, tłumacząc tego typu jednostki, często stosuje opuszczenia i translaty w formie adaptowanej. Być może taka strategia - ukierunkowana na ułatwienie odbioru dzieła - podyktowana była faktem, że pozycja adresowana jest do uczniów szkół ponadpodstawowych. W związku z czym dbałość o walory poznawcze nie stała się celem nadrzędnym autorki przekładu i ustąpiła miejsca przystępności w odbiorze powieści (Sadowska 2018: 153). 
Konkluzja ta nie tylko przybliża czytelnikom jeden z czynników wpływających na różnice między przekładami, ale też pośrednio wyjaśnia przyczyny nadzwyczajnego i gwałtownego powiększenia serii przekładowej Mistrza i Małgorzaty, które postawiło czytelników przed niełatwym wyborem.

Inaczej wygląda sytuacja w przypadku poszukiwania w internecie informacji na temat tłumaczenia Krzysztofa Tura - tutaj znajdziemy w wyszukiwarce głównie księgarnie internetowe i portale poświęcone książkom (np. Lubimyczytać.pl), a te w większości powtarzają fragmenty recenzji zamieszczone na okładce wydania i spełniające funkcje marketingowe, o czym wspominałam powyżej.

Jeszcze innym - i chyba najbardziej złożonym - zjawiskiem jest obecność w sieci tłumaczenia rodziny Przebindów (małżeństwa filologów - Grzegorza i Leokadii oraz ich syna Igora). Tutaj mamy do czynienia przede wszystkim z wypowiedziami samych tłumaczy. Na wysoko pozycjonowanej stronie Grzegorza Przebindy znajduje się wręcz całe archiwum wywiadów dla radia, prasy i telewizji. Materiały te dostarczają bezcennych informacji zarówno na temat procesu przekładu, jak i samego oryginału - Grzegorz Przebinda, profesor Uniwersytetu Jagiellońskiego, jest wszak uznanym bułhakologiem, twórcą przypisów oraz opracowania przekładu Lewandowskiej i Dąbrowskiego wydanego w serii Biblioteka Narodowa, a także autorem takich publikacji, jak ,,Sto dwadzieścia jedna Matgorzata”. O tekście pierwszego polskiego przekładu „Mistrza i Małgorzaty” czy Mogarycz i inni. Dramatyczne losy kanonu tekstowego „Mistrza i Małgorzaty”. Nie należy jednak zapominać, że zgromadzone na jego stronie teksty pełnią również funkcję autopromocyjną. To warte odnotowania zjawisko, gdy thumacze mają już nie tylko możliwość ,wy-tłumaczenia się” w paratekstach do przekładów (Balcerzan 2011: 177), ale też dotarcia do szerokiego kręgu odbiorców poprzez media. Sprawa jest na tyle złożona i interesująca, że zasługuje na osobne studium. W niniejszym artykule, który dotyczy obecności krytyki przekładu w internecie, ograniczę się do odnotowania, że w gąszczu promocyjnych i autopromocyjnych tekstów na temat tłumaczenia Przebindów z trudem można odnaleźć artykuł Marii Mocarz-Kleindienst pt. Dlaczego powstaja nowe przekłady? „Mistrz i Matgorzata” Michaiła Buthakowa w nowym tłumaczeniu na język polski, który w całości poświęcony jest właśnie temu przekładowi i w dużej mierze opisanym powyżej zjawiskom. Autorka recenzji ocenia tłumaczenie Przebindów zdecydowanie pozytywnie. $\mathrm{Z}$ aprobatą prezentuje przykłady uwspółcześnienia języka w stosunku do przekładu Lewandowskiej i Dąbrowskiego (Mocarz-Kleindienst 2018: 272), 
przychylając się do tezy Paula Bensimona, ,iż każde pokolenie powinno posiadać własne tłumaczenie" (Mocarz-Kleindienst 2018: 269). Niestety nie konfrontuje jednak wersji rodziny Przebindów z innymi współczesnymi tłumaczeniami (choć odnotowuje publikacje przekładów Cichockiego i Tura). Ze szczególnym uznaniem Mocarz-Kleindienst pisze o obszernych, erudycyjnych i wielofunkcyjnych przypisach wyróżniających to thumaczenie (jak sobie możemy dopowiedzieć) spośród innych wersji:

Zatem próbując odpowiedzieć na zawarte w tytule pytanie: dlaczego thumaczymy?, można konstatować, że zafascynowana arcydziełem Bułhakowa rodzina Przebindów postanowiła ponownie zaproponować jego lekturę w nowej odsłonie: z zachowaniem specyfiki kultury oryginału, ułatwiając jego recepcję dzięki nietuzinkowym komentarzom, które można czytać jako odrębne dzieło (Mocarz-Kleindienst 2018: 278).

Ostatnie słowa przytoczonego powyżej fragmentu są zaskakująco zbieżne z rozpowszechnionym w internecie blurbem do wydania przekładu Przebindów, w którym napisano: „To prawdopodobnie pierwszy przypadek, gdy przypisy czyta się z równą fascynacją, co tekst samej powieści” (opis wydawcy, 2021). Czytelnicy-internauci odnajdą je niestety szybciej i łatwiej niż artykuł Mocarz-Kleindienst, opublikowany online w czasopiśmie naukowym pt. „Przekłady Literatur Słowiańskich”.

Gdy wpisuję do wyszukiwarki frazę "mistrz i małgorzata tłumaczenia" (17 lutego 2021 roku), przed artykułem Mocarz-Kleindienst pojawia się między innymi odsyłacz do witryny Turbotłumaczenia.pl - biura tłumaczeń, na którego stronie prowadzony jest też blog poświęcony rozmaitym zagadnieniom szeroko rozumianego przekładu. To tam znajdziemy wpis pt. Które tlumaczenie „Mistrza i Małgorzaty” warto wybrać?, opublikowany pod koniec 2020 roku przez użytkownika podpisującego się TurboMariusz. Nie zamierzam szczegółowo omawiać tego tekstu, ponieważ stanowi on w dużej mierze streszczenie artykułu Bożeny Witowicz. Tym, co może w nim przyciągnąć uwagę czytelników, jest bardzo klarowne i zwięzłe omówienie historii powstawania kolejnych przekładów i informacji o konkretnych wersjach oryginału, na których je oparto. Brak tu jednak elementów filologicznej analizy - porównania choćby krótkich fragmentów tekstów. Podsumowując: trudno zakwalifikować ten wpis jako recenzję, tym bardziej, że nie podejmuje nawet próby udzielenia odpowiedzi na tytułowe pytanie, lecz lakonicznie puentuje: „Najlepiej przekonać się o tym osobiście, ponieważ każde z nich jest unikalne, będąc swoistą interpretacją dzieła Bułhakowa” (TurboMariusz 2020). 
Zgadzam się z Ewą Kraskowską, która napisała, że „im więcej krytyki translatorskiej w najróżniejszych formach i mediach, tym wyższa świadomość przekładowa w kręgach uczestników i użytkowników kultury" (Kraskowska 2018: 55). Problem polega jednak na tym, że to, co niegdyś potocznie mówiono o papierze, można dziś powiedzieć o cyberprzestrzeni: przyjmie wszystko. Poszukując w niej informacji na temat tłumaczeń wybranego dzieła, natrafiamy zarówno na recenzje, treści marketingowe udające teksty krytyczne, wreszcie teksty naukowe zawierające pewne elementy krytyki przekładu, dostępne dzięki strategii open access - cenne, lecz często napisane w sposób mało przystępny dla niewprawnego czytelnika. Nic dziwnego, że w tej sytuacji czytelnicy-konsumenci, zagubieni w gąszczu tekstów, zdani na najłatwiej dostępne i najlepiej widoczne „gwiazdki” oraz komentarze wystawiane przez innych konsumentów, odczuwają brak rzetelnej, ale i przystępnej formy krytyki przekładu, a swoje niezadowolenie wyrażają m.in. w żądaniach zwrotu pieniędzy za zakupiony „towar”.

Rozwój krytyki przekładu, której powinnością jest - jak pisał cytowany na początku niniejszego artykułu Edward Balcerzan - ,aktywność aksjologiczna”, winien być naturalną konsekwencją przemian zachodzących na rynku wydawniczym: w sieci powinny być widoczne i łatwo dostępne dla przeciętnego internauty przede wszystkim recenzje pisane przez znawców. $\mathrm{Z}$ jednej strony ich głos musi być donośny i wyrazisty, by przebić się przez chaos internetowych komentarzy, z drugiej zaś - na tyle jasny i klarowny, aby pomóc czytelnikom zorientować się w różnorodności utworów sprzedawanych pod tą samą nazwą i uwrażliwić ich na walory literackie tekstów kryjących się za atrakcyjnymi okładkami nowych wydań. Wydaje się, że w cyberprzestrzeni to właśnie profesjonalne recenzje mają największe szanse i możliwości osiągnięcia sformułowanego przez Edwarda Balcerzana celu krytyki przekładu, jakim jest „utrzymanie w świadomości czytelnika” faktu, że „odmienność od oryginału stanowi konstytutywną cechę przekładu «jako takiego»" (Balcerzan 2011: 181).

\section{Bibliografia}

Balcerzan, Edward. 2011. Tajemnica istnienia (sporadycznego) krytyki przektadu, w: E. Balcerzan, Thumaczenie jako ,, wojna światów”. W kręgu translatologii i komparatystyki, Poznań: Wydawnictwo Naukowe UAM, s. 173-186. 
Barańska, Joanna. 2021. Gniew czytelnika. Co można wyciąć z książki w XXI w.?, Onet. pl, [online] https://kultura.onet.pl/ksiazki/bracia-karamazow-wydawnictwa-mg-niekompletna-ksiazka-dlaczego/8zyz992 [dostęp: 17 lutego 2021].

Bułhakow, Michaił. 1990. Mistrz i Małgorzata, przeł. I. Lewandowska, W. Dąbrowski, wstęp A. Drawicz, oprac. tekstu i przypisy G. Przebinda, Wrocław: Ossolineum.

Buzeli, Hélène. 2007. Translation 'in the Making', w: M. Wolf, A. Fukari (red.), Constructing a Sociology of Translation, Amsterdam: John Benjamins s. 135-169.

Heilbron, Johan, Sapiro, Gisèle. 2007. Outline for a Sociology of Translation. Current Issues and Future Prospects, w: M. Wolf, A. Fukari (red.), Constructing a Sociology of Translation, Amsterdam: John Benjamins, s. 93-107.

Kraskowska, Ewa. 2018. Porównywanie jako metoda krytyki przekładu, „Tekstualia” 3(54), s. 53-63.

Mocarz-Kleindienst, Maria. 2018. Dlaczego powstaja nowe przektady? „,Mistrz i Matgorzata” Michaiła Buthakowa w nowym tłumaczeniu na język polski, „Przekłady Literatur Słowiańskich" T. 9 cz.1, s. 267-281.

Przebinda, Grzegorz. 2019. Mogarycz i inni. Dramatyczne losy kanonu tekstowego „,Mistrza i Małgorzaty”, „Przegląd Rusycystyczny” 3(167), s. 36-90.

- 2017. „Sto dwadzieścia jedna Matgorzata”. O tekście pierwszego polskiego przekładu ,Mistrza i Małgorzaty”, „Przegląd Rusycystyczny” 2 (158), s. 54-79.

Sadowska, Monika. 2018. Elementy trzeciej kultury w przekładach polskich wersji „Mistrza i Małgorzaty” Michaiła Buthakowa, „Acta Polono-Ruthenica” XXIII/3, s. 141-155.

Wardle, Mary. 2019. Eeny, Meeny, Miny, Moe: The Reception of Retranslations and How Readers Choose, „Cadernos de traduçao” 39(1), s. 216-238.

Wawrzyńczak, Aleksander. 2019. Buthakow zmanipulowany, czyli o "fachowym i wybitnym” przekładzie „Mistrza i Małgorzaty”, „Przegląd Rusycystyczny” 3(167), s. 105-122.

Witowicz, Bożena. 2018. Narzan, zubrik i pepegi, „Przegląd” 1, [online] https://www. tygodnikprzeglad.pl/narzan-zubrik-pepegi/ [dostęp: 12 lutego 2021].

Wołodźko-Butkiewicz, Alicja. 2016. [recenzja przekładu], w: M. Bułgakow, Mistrz i Matgorzata. Czarny Mag, przeł. K. Tur, Białystok: Fundacja Sąsiedzi.

\section{Źródła internetowe}

https://turbotlumaczenia.pl/blog/ktore-tlumaczenie-mistrza-i-malgorzaty-warto-wybrac/

[dostęp: 15 listopada 2021].

https://www.fundacja-sasiedzi.org.pl/wydawnictwa/193-michal-bulgakow-mistrz-i-malgorzata-nowe-tlumaczenie.html [dostęp: 19 sierpnia 2021].

https://www.etiuda.net/p777,mistrz-i-maglgorzata.html [dostęp: 15 listopada 2021]. https://www.wydawnictwoznak.pl/ksiazka/Mistrz-i-Malgorzata/7641 [dostęp: 15 listopada 2021].

http://przebindapisze.pl/category/mistrz-i-malgorzata/ [dostęp: 19 sierpnia 2021]. https://www.bellona.pl/tytul/mistrz-i-malgorzata/ [dostęp: 15 listopada 2021]. 